\title{
Genetic Variability and Identification of the Intermediate Snail Hosts of Schistosoma mansoni
}

\author{
Teofânia HDA Vidigal/*, Emmanuel Dias Neto***, Linus Spatz**, Diana N \\ Nunes***, Edina R Pires***, Andrew JG Simpson***, Omar S Carvalho/ ${ }^{+}$
}

\author{
Centro de Pesquisas René Rachou-Fiocruz, Av. Augusto de Lima 1715, 30190-002 Belo Horizonte, MG, Brasil \\ *Departamento Zoologia, UFMG, Belo Horizonte, MG, Brasil **Facultad de Medicina Universidad de Buenos \\ Aires, Argentina ***Instituto Ludwig de Pesquisa sobre o Câncer, São Paulo, SP, Brasil
}

Studies based on shell or reproductive organ morphology and genetic considerations suggest extensive intraspecific variation in Biomphalaria snails. The high variability at the morphological and genetic levels, as well as the small size of some specimens and similarities between species complicate the correct identification of these snails. Here we review our work using methods based on polymerase chain reaction $(P C R)$ amplification for analysis of genetic variation and identification of Biomphalaria snails from Brazil, Argentina, Uruguay and Paraguay. Arbitrarily primed-PCR revealed that the genome of B. glabrata exihibits a remarkable degree of intraespecific polymorphism. Low stringencyPCR using primers for $18 S$ rRNA permited the identification of $\mathrm{B}$. glabrata, B. tenagophila and B. occidentalis. The study of individuals obtained from geographically distinct populations exhibits significant intraspecific DNA polymorphism, however specimens from the same species, exhibit some species specific LSPs. We also showed that PCR-restriction fragment of length polymorphism of the internal transcribed spacer region of Biomphalaria rDNA, using DdeI permits the differentiation of the three intermediate hosts of Schistosoma mansoni. The molecular biological techniques used in our studies are very useful for the generation of new knowledge concerning the systematics and population genetics of Biomphalaria snails.

Key words: Biomphalaria - snails - genetic variability - identification - polymerase chain reaction

Biomphalaria snails are found both in Africa and in the Americas. In both continents members of this genus serve as intermediate hosts for the parasitic trematode Schistosoma mansoni. In Brazil ten species of Biomphalaria are recognized although only $B$. straminea, B. tenagophila and $B$. glabrata are found naturally infected with the parasite. Of these, the latter is the most important due to its wide distribution and its high susceptibility to S. mansoni (Paraense \& Corrêa 1963). These snails are hermaphrodites and can self-fertilize but prefer to reproduce by cross-fertilization when paired. These biological characteristics are evolutionarily very important, providing the organism with the ability to establish colonies from an individual organism while maintaining genetic variation through sexual reproduction (Paraense 1955). Most populations are under significant environmental pressures (rains and droughts) that can dramatically reduce population levels, requiring

Partially supported by FAPEMIG, CAPES, PIBIC/ FIOCRUZ, Fundación Roemmeres and Conicet.

${ }^{+}$Corresponding author. Fax: +55-31-295.3115.

Received 4 May 1998

Accepted 31 August 1998 recolonization from the low number of remaining snails (Paraense 1955). There are two points to be highlighted: (1) the re-building of a new population from a few surviving individuals (founder effect) could explain low intrapopulation variability. Jarne and Delay (1991) reported that self-fertilization can be selected under certain circunstances such as low population density or local environmental conditions, also supporting the low intra population variability. In addition, the fixation of these populations may occur in a very short period of time, due to the high reproduction potential of the species, enhanced by the absence of intra-specific competition (Paraense et al. 1955); (2) the limited gene flow (a lack of interconnecting waterways) between different populations could facilitate the formation of local strains, resulting in interpopulational variability. It has been proposed that genetic drift working in populations under strong environmental pressures, could be responsible for the genetic heterogenety, patchy distribution of susceptibility to $S$. mansoni among snail populations and also lead to a population structure characterized by relative genetic homogeneity within, and differentiation among local snails populations (Paraense 1955, Michelson \& Dubois 1978, Mulvey \& Vrijenhoek 1982). The observation of several levels of reproductive iso- 
lation detected in allopatric conspecific individuals also indicate extensive genetic heterogeneity among populations of Biomphalaria snails from separate localities (Paraense 1959).

The identification of Biomphalaria species is important for epidemiological studies of schistosomiasis. For a long time malacologists have been looking for characters that could aid in the specific identification of these snails. Their morphological identification is based mainly on the reports of Deslandes (1951) and Paraense (1975, 1981, 1984,1988 ) which use shell and reproductive organ morphology. The high variability of these characters, the environmental influence on shell size and shape, the small size of specimens, and the similarity between some species, complicate specific identification, specially for non-experts.

Isozyme patterns have been useful for the specific identification of Bulinus and Biomphalaria snails as well as for investigating the phylogenetic relationships and genetic structure of these groups (Mulvey \& Vryenhoeck 1981, Jelnes 1986, Mascara \& Morgante 1991, 1995, Bandoni et al. 1995). Recently, molecular biology techniques have been introduced for the study of freshwater snails (Jarne et al. 1990, 1992, Knight et al. 1991, Strahan et al. 1991, Langand et al. 1993, Stothard \& Rollinson 1996, Stothard et al. 1996, Stothard \& Rollinson 1997, Remigio \& Blair 1997, Lewis et al. 1997). We here describe our work with Biomphalaria snails using three techniques based on the polymerase chain reaction (PCR).

\section{ANALYSIS OF GENETIC VARIATION IN BRAZILIAN ISOLATES OF B. GLABRATA SNAILS BY AP-PCR}

AP-PCR (arbitrarily primed polymerase chain reaction - Welsh \& McClelland 1990, Williams et al. 1990) has been used to study genomic variability in different groups of organisms (Dias Neto et al. 1993 b,c, Noyes et al. 1996, Barral et al. 1996) including molluscs (Crossland et al.1993, Langand et al. 1993, Larson et al. 1996, Stothard \& Rollinson 1996). A recent report by Lewis et al. (1997) showed some promising results with the AP-PCR approach in analysis of $B$. glabrata populations resistant and susceptible to infection with $S$. mansoni, where a $1.3 \mathrm{~kb}$ marker appears in nearly all resistant progeny and $1.1 \mathrm{~kb}$ marker appears in all susceptible progeny. We used AP-PCR to estimate intra and interpopulation variability of $B$. glabrata from different localities of Brazil (Vidigal et al. 1994). We first compared specimens of two field populations from different localities and found a limited intrapopulation heterogenity in contrast to the high interpopulation heterogenity observed. These results suggest that each population is highly homogeneous but that the global B. glabrata popu- lation is highly heterogeneous. This was found to be true when any two of the isolates were compared using any of the five different primers tested. Snails reared and mantained for different periods of time were also analyzed, showing no differences in intrapopulation variability levels when compared with field populations. This rules out the possibility that selective breeding in the laboratory had produced inbred strains, irrespective of the length of time of maintenance in the laboratory. The high level of genetic variability found in B. glabrata was confirmed by amplifying two individuals selected at random from each of six populations, either from laboratories or the field (Fig. 1) from different regions of the country, using primers 3307 and 3302 (Fig. 2). Less than $10 \%$ of the amplified fragments were present in all of the analyzed samples. The average percentage of shared bands between each pair from the same locality was $74.5 \%$ and between all possilble pairs from different localities was $43 \%$. These results agree with those obtained for B. glabrata in Puerto Rico and in $B$. prona using isoenzymes (Mulvey \& Vrijenhoek 1982, Mulvey et al. 1988, Paraense et al. 1992), or for Bulinus snails using RAPD analysis (Langand et al. 1993). The high variability of B. glabrata $(90 \%)$ is in contrast with that of Schistosoma $(10 \%)$. The fact that only approx-imately $5 \%$ of RAPDs products obtained for the different schistosome strains are polymorphic (Barral et al. 1993, Dias Neto et al. 1993b), would indicate the higher relevance of molluscan genetics over parasite genetics in determing the epidemiology of the disease (Simpson et al. 1995).

From the technical point of view, our data showed that AP-PCR analysis is highly appropiate for the study of Biomphalaria genetics since it confirmed the extensive variability that had been observed by isoenzyme analysis and morphological studies in B. glabrata.

\section{SPECIFIC IDENTIFICATION OF BIOMPHALARIA SNAILS BY LS-PCR}

The remarkable degree of intraspecific polymorphism detected in B. glabrata by AP-PCR suggested us that this technique would be extremely difficult to use for species identification. We tested the low stringency polymerase chain reaction (LSPCR) which uses two specific primers and low stringency annealing conditions since products obtained from the highly conserved rRNA genes have less intraspecific variation than those from randomly amplified sequences (Dias Neto et al. 1993a, Vidigal et al. 1996). Several primers were tested for their ability to group specimens of the same species. Primers NS-1 and ET-1 gave the best results when they were tested with $B$. glabrata 
and B. tenagophila samples taken from six localities in Brazil (Vidigal et al. 1996). Even though these primers produced a complex pattern of bands in LS-PCR analysis, at least four LS products for each Biomphalaria were species-specific, independent of the origin of the snails (Fig. 3). We could also confirm that $B$. glabrata is more heterogeneous than $B$. tenagophila. Using this technique, it was also possible to distinguish $B$. tenagophila from B. occidentalis (Pires et al. 1997). These two species are not distinguishable by most morphologic characters (Paraense 1981) but only B. tenagophila is an intermediate host of $S$. mansoni. Previous experiments using this technique with $B$. straminea suggested that this species presents higher interpopulation levels of variability than B. glabrata, $B$. tenagophila or B. occidentalis. No sharing of LS products was observed on analyzing several $B$. straminea specimens from different localities (data not shown). Although LS-PCR did not allow specific identification of $B$. straminea snails, they can not be mistaken with $B$. glabrata, B. tenagophila or $B$. occidentalis. In summary we show that LSPCR permits the differentiation $B$. glabrata and $B$. tenagophila and very similar species such as $B$. tenagophila and B. occidentalis (Vidigal et al. 1996, Pires et al. 1997).

\section{SPECIFIC IDENTIFICATION OF BIOMPHALARIA SNAILS BY PCR-RFLP}

Although very useful for identifying some species of Biomphalaria, the complexity of the patterns produced by LS-PCR represents a problem as it requires the correct identification of a few bands out of dozens. To obtain a less variable marker for the study of these molluscs, we have analyzed possible sequence polymorphisms in the ITS (internal transcribed spacer) region of the rDNA (which includes the 5.8S rDNA gene together with the flanking ITS1 and ITS2 spacers) by amplification using PCR and digestion with several restriction enzymes (restriction fragment length polymorphism - RFLP) (Vidigal et al. 1998). This method has been successfully employed to distinguish closely related parasitic worms (Gasser et al. 1996, Cunningham 1997) and in studies of genetic variation and identification of species of snails such as Oncomelania hupensis, Bulinus and Stagnicola (Hope \& McManus 1994, Stothard et al.1996, Stothard \& Rollinson 1997, Remigio \& Blair 1997). We first analyzed different $B$. glabrata, B. tenagophila and $B$. straminea populations in Brazil. The entire ITS was amplified using the primers ETTS1 and ETTS2 anchored respectively in the conserved extremities

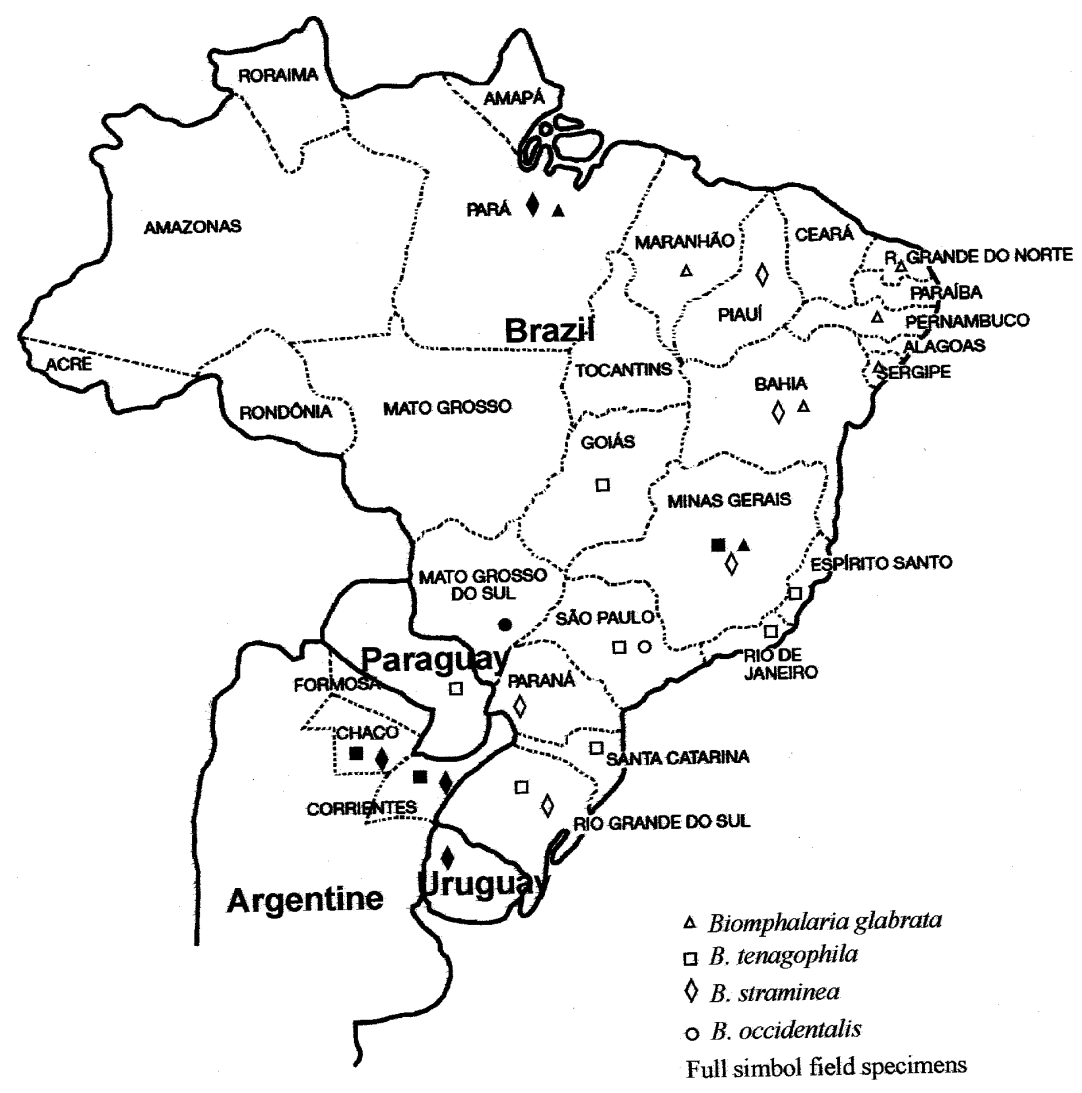

Fig. 1: geographical distribution of the snails used. 
of the $18 \mathrm{~S}$ and $28 \mathrm{~S}$ ribosomal genes, according to described techniques (Kane \& Rollinson 1994, Stothard et al. 1996). The PCR specific amplification of the Biomphalaria ITS resulted in a product of approximately $1.3 \mathrm{~kb}$ independent of the species. The ITS region amplified from all the species studied has sites for the restriction enzymes AluI, DdeI, HaeIII, MnlI, MspI, RsaI and Sau3aI but not for Hinfl. Restriction fragments were separated by $6 \%$ or $8 \%$ polyacrylamide gel electrophoresis and stained with silver. Profiles obtained with $A l u \mathrm{I}, M n l \mathrm{I}$, Sau $3 a \mathrm{I}, M s p \mathrm{I}$ and $R s a \mathrm{I}$ did not permit species identification as extensive intraspecific polymorphism or invariant RFLP profiles were detected. The most promising RFLP profiles were those produced both with HaeIII and DdeI which included invariant species-specific products for three representative specimens of B. glabrata, B. tenagophila and $B$. straminea (Fig. 4). The reproducibility of the DdeI
- ITS RFLP profiles was demonstrated by analysis of diverse Biomphalaria specimens obtained from distinct localities within Brazil. Additional snails from Argentina (B. straminea and B. tenagophila), Uruguay ( $B$. straminea) and Paraguay $(B$. tenagophila) were included in the analysis. The restriction profiles of $B$. straminea from Argentina and Uruguay, also showed the same two characteristic fragments present in the Brazilian isolates (data not shown). When B. tenagophila from different localities within Argentina, were compared with specimens from Brazil and Paraguay, the profiles of the specimens from Argentina appear quite distinct with two additional fragments that are absent in the other B. tenagophila specimens tested. However, in all B. tenagophila specimens the presence of a band of approximately $470 \mathrm{bp}$, was observed allowing identification (Fig. 5). Our results also showed the possibility of using eggs for snail
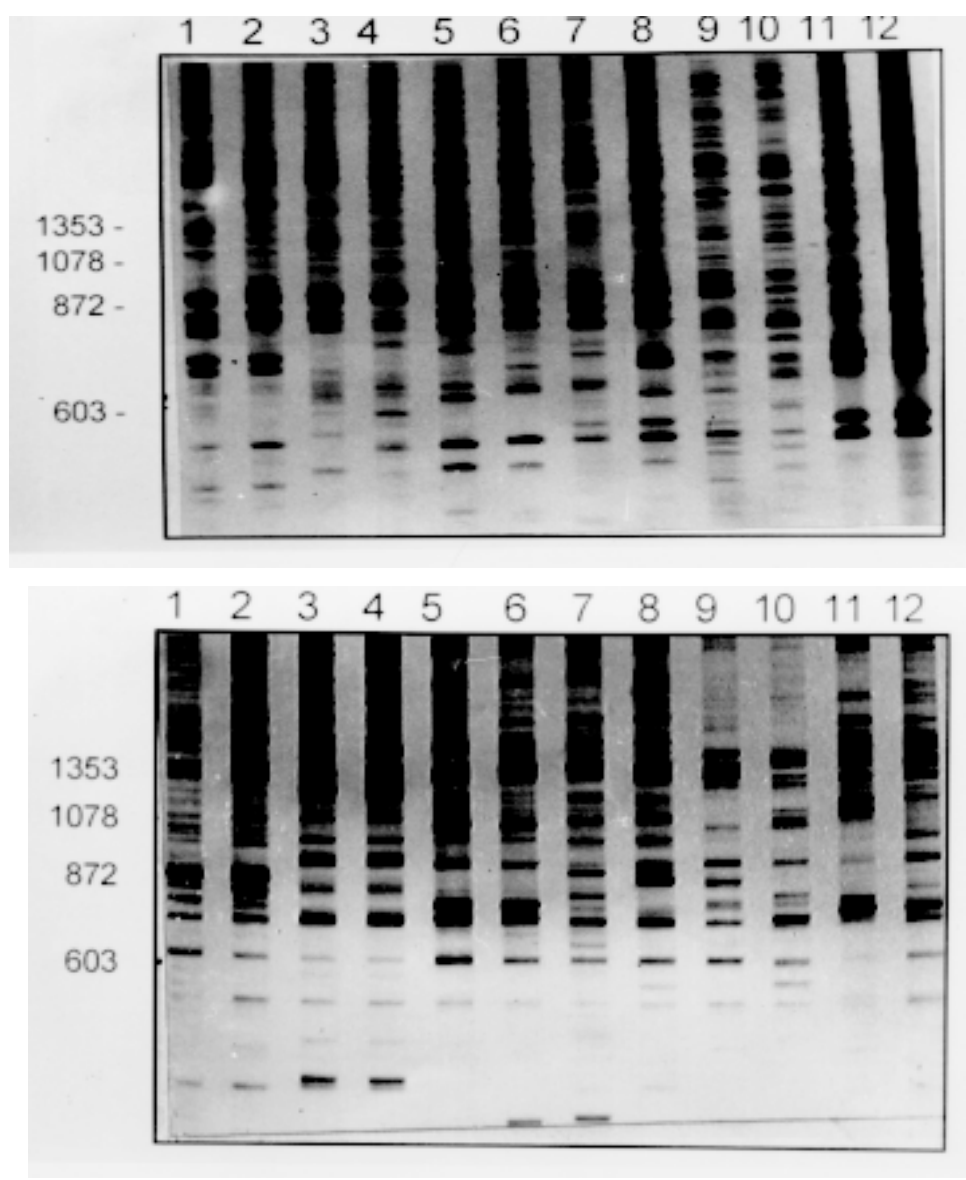

Fig. 2: RAPD profiles of two distinct Biomphalaria glabrata specimens from six different geographical regions using one ng of template and primers 3307(A) and 3302 (B). Lanes 1 and 2: two individuals from Belém, PA; lanes 3 and 4: two individuals from Cururupu, MA; lanes 5 and 6: two individuals from Touros, RN; lanes 7 and 8: two individuals from Pontezinha, PE; lanes 9 and 10: two individuals from Aracaju, SE; lanes 11 and 12: two individuals from Jacobina, BA. The PCR products were resolved by electrophoresis through a $4 \%$ polyacrylamide gel followed by silver staining.

(Source: Exp Parasitol 79: 187-194, 1994). 


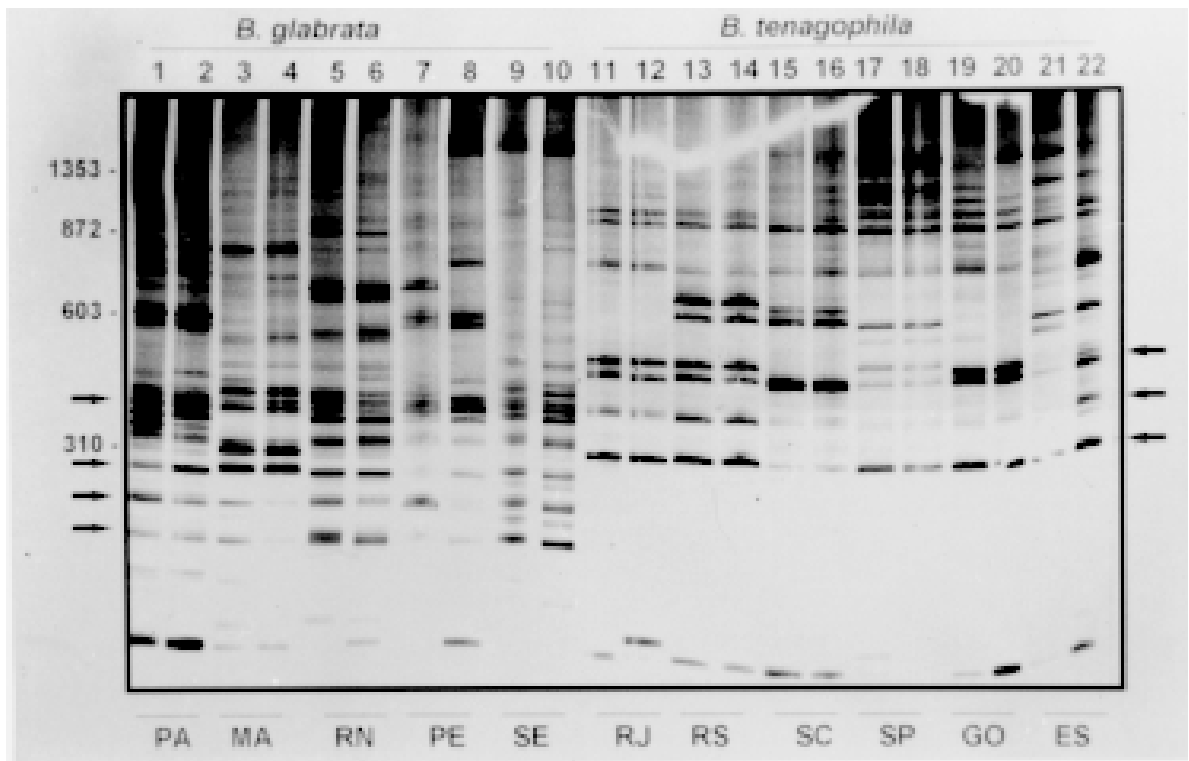

Fig. 3: silver-stained 4\% polyacrylamide gel showing the LS-PCR amplification products obtained with primers NS1-ET1 and 1ng of DNA extracted from snails obtained from different localities. Lanes 1 and 2: Biomphalaria glabrata from Belém, PA; lanes 3 and 4: B. glabrata from Cururupu, MA; lanes 5 and 6: B. glabrata from Touros, RN; lanes 7 and 8: B. glabrata from Pontezinha, PE; lanes 9 and 10: B. glabrata from Aracaju, SE; lanes 11 and 12: B. tenagophila from Paracambi, RJ; lanes 13 e 14: B. tenagophila from Imbé, RS; lanes 15 and 16: B. tenagophila from Joinville, SC; lanes 17 and 18: B. tenagophila from Araçatuba, SP; lanes 19 and 20: B. tenagophila from Formosa, GO; lanes 21 and 22: B. tenagophila from Vila Velha, ES. The species diagnostic bands are indicated by arrows, and the molecular weight markers, are as shown.

(Source: Mem Inst Oswaldo Cruz 91: 739-744, 1996).

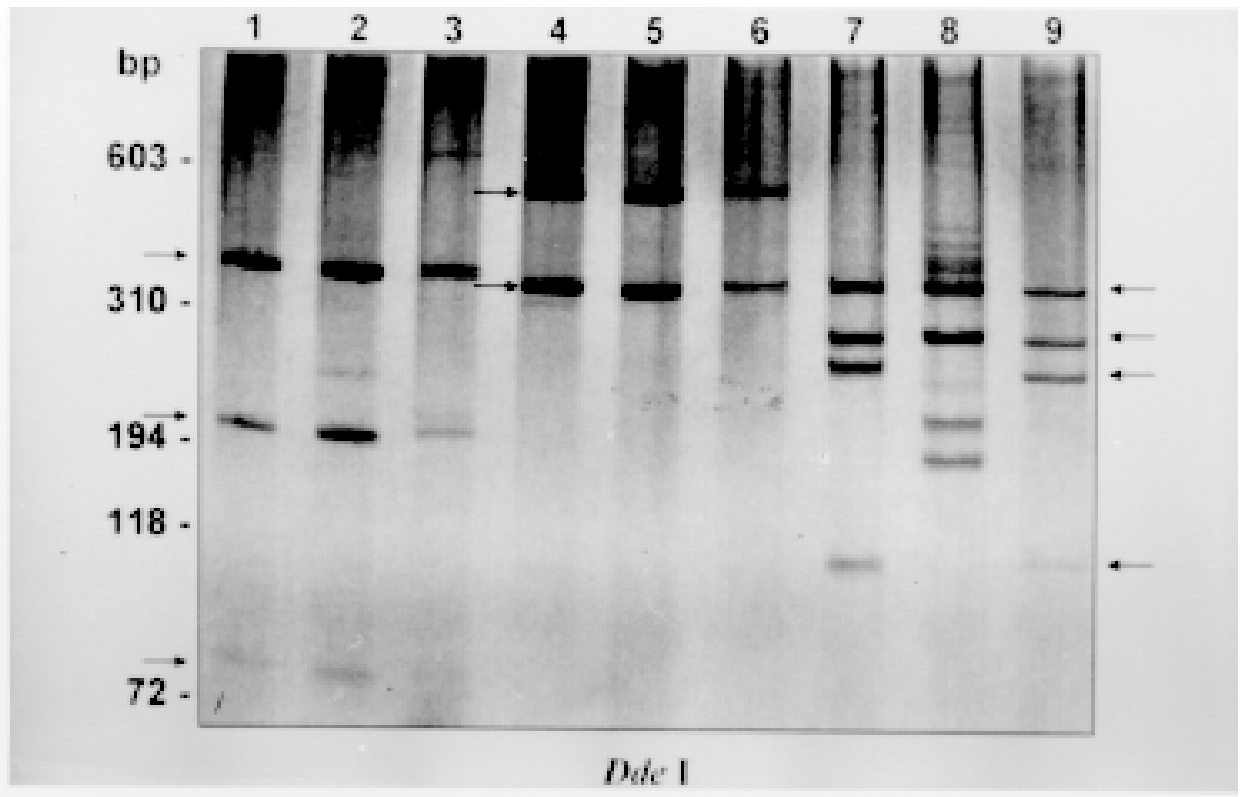

Fig. 4: $6 \%$ silver stained polyacrylamide gels showing the RFLP profiles obtained following the digestion of the rDNA ITS with DdeI. The snail species are: lane 1: Biomphalaria glabrata from Belém, PA; lane 2: B. glabrata from Aracaju, SE; lane 3: B. glabrata from, Sabará, MG; lane 4: B. tenagophila from Formosa, GO; lane 5: B. tenagophila from Vespasiano, MG; lane 6, B. tenagophila from Vitória, ES; lane 7: B. straminea from Picos, PI; lane 8: B. straminea from Porto Alegre, RS; lane 9: B. straminea from Várzea do Poço, BA. Molecular size markers are shown on the left of each gel. The arrows indicate species specific fragments. (Source: Exp Parasitol 89: 180-187, 1998). 


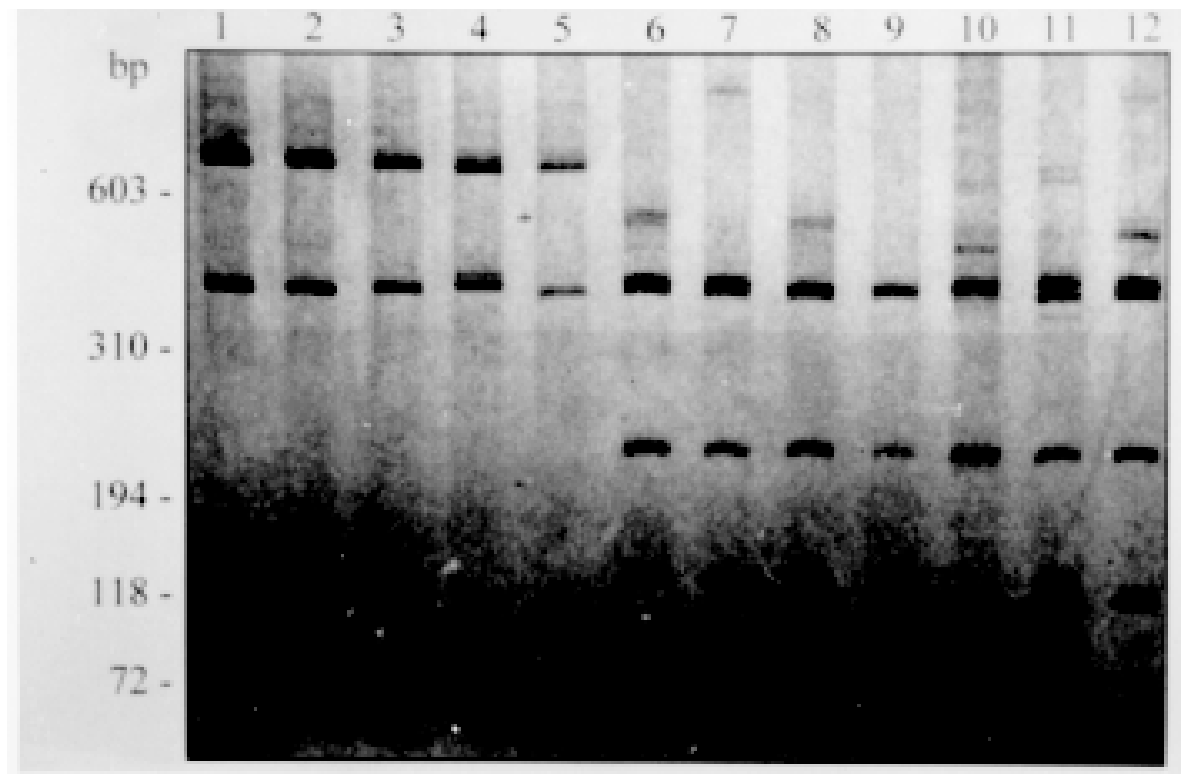

Fig. 5: 6\% silver stained polyacrylamide gel showing the RFLP profiles obtained by digesting the rDNA ITS with DdeI. The DNA was extracted from individual Biomphalaria tenagophila snails derived from: lane 1, Formosa, State of Goiás; lane 2, Vespasiano, State of Minas Gerais; lane 3, Imbé, State of Rio Grande do Sul; lanes 4 and 5, Assuncion, Paraguay; lanes 6 to 8, Resistência (Chaco), Argentina; lanes 9 to 12, Corrientes, Argentina. Molecular size markers are shown on the left of the gel. (Source: Exp Parasitol 89: 180-187, 1998)

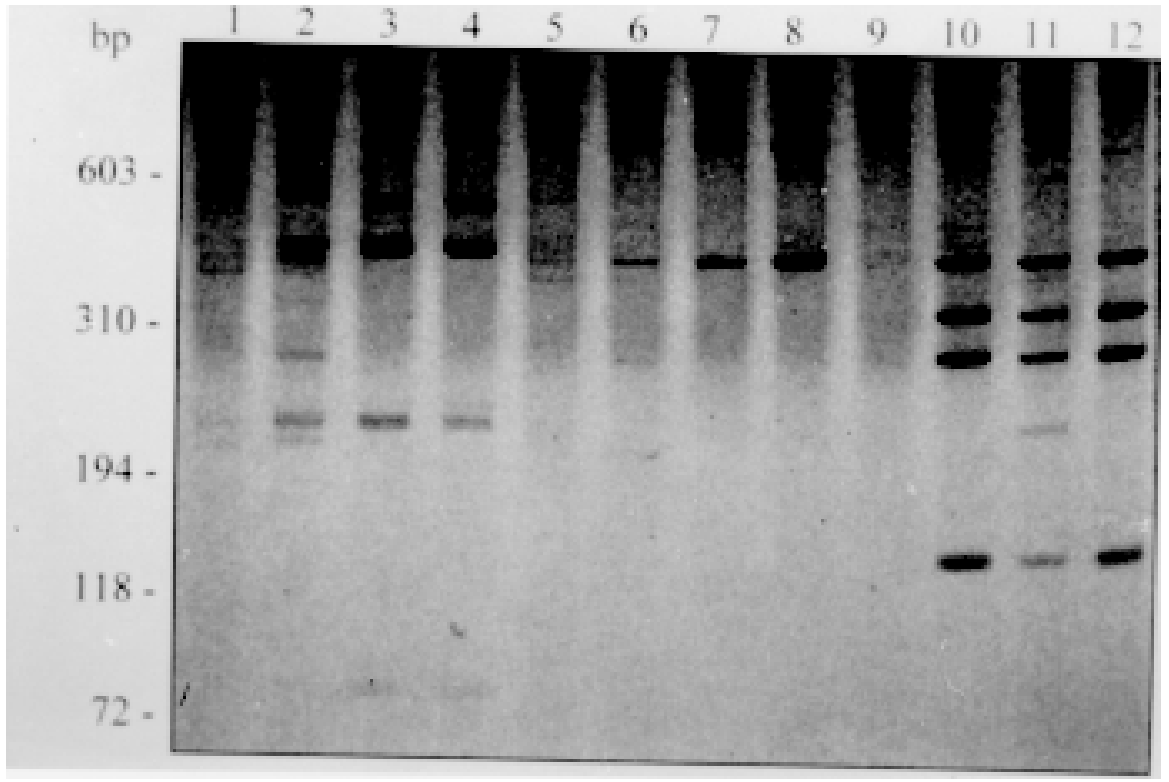

Fig. 6: 6\% silver stained polyacrylamide gel showing the RFLP profiles obtained after digesting of the rDNA ITS with DdeI. The DNA used was extracted from the eggs of Biomphalaria glabrata, B. tenagophila and B. straminea on different days and compared with the profile produced with adult control DNA. Lane 1, day one eggs of B. glabrata; lane 2, day two eggs of $B$. glabrata; lane 3, day three eggs of $B$. glabrata; lane 4, adult B. glabrata; lane 5, day one eggs of B. tenagophila; lane 6 , day two eggs of $B$. tenagophila; lane 7, day three eggs of $B$. tenagophila; lane 8 , adult $B$. tenagophila; lane 9 , day one eggs of $B$. straminea; lane 10 , day two eggs of $B$. straminea; lane11, day three eggs of $B$. straminea; lane 12 , adult $B$. straminea. (Source: Exp Parasitol 89: 180-187, 1998) 
identification with DdeI (Fig. 6). This possibility has important practical implications when the number of collected specimens is low, permitting the maintenance of live adults in the laboratory for further studies. In summary we show here that PCR-RFLP of the ITS region using a single enzyme (DdeI), permits the differentiation of the three intermediate hosts of $S$. mansoni from South America. The technique is simple and rapid and may represent an important advance in the precision of snail population surveys undertaken in South America. To understand better the relationships between the different species, as well as the relations between the isolates that resulted in more polymorphic profiles (as seen in B. tenagophila from Argentina or in B. straminea from Porto Alegre) the sequencing of the ITS region is being undertaken. The molecular biological techniques used in our studies are very useful for the generation of new knowledge concerning the systematics and population genetics of Biomphalaria snails.

\section{ACKNOWLEDGEMENTS}

To Dr W Lobato Paraense and Dr Lygia Corrêa from the Departamento de Malacologia, Instituto Oswaldo Cruz, who gave us some snails. To David Rollinson of the Natural History Museum, London, for providing the oligonucleotide primers. To SM Gonzáles Cappa for making avaiable the facilities in the development of the project; to Roberta Lima Caldeira by technical assistance, and to Letícia Peixoto Santos by invaluable administrative support.

\section{REFERENCES}

Bandoni SM, Mulvey M, Loker ES 1995. Phylogenetic analysis of eleven species of Biomphalaria Preston, 1910 (Gastropoda: Planorbidae) based on comparisions of allozymes. Biol J Linn Soc 54: 127.

Barral V, Morand S, Pointier JP, Théron A 1996. Distribution of schistosome genetic diversity within naturally infected Rattus rattus detected by RAPD markers. Parasitology 113: 511-517.

Barral V, This P, Imbert-Estabelet D, Combes C, Delsneny M 1993. Genetic variability and evolution of the Schistosoma genome by using random amplified polymorphic DNA markers. Mol Biochem Parasitol 59: 211-222.

Crossland S, Coates D, Grahame J, Mill PJ 1993.Use of random amplified polymorphic DNAs (RAPDs) in separating two sibling species of Littorina. Mar Ecol Prog Ser 96: 301-305.

Cunningham CO 1997. Species variation within the internal transcribed spacer (ITS) region of Gyrodactylus (Monogenea: Gyrodactylidae) ribosomal RNA genes. J Parasitol 83: 215-219.

Deslandes N 1951. Técnica de dissecação e exame de planorbídeos. Rev Serv Espec Saúde Púb 4: 371-382.

Dias Neto E, Santos FR, Pena SDJ, Simpson AJG 1993a. Sex determination by Low Stringency PCR (LS-
PCR). Nucl Acids Res 21: 763-764.

Dias Neto E, Souza CP, Rollinson D, Katz N, Pena SDJ, Simpson AJG 1993b. The random amplification of polymorphic DNA allows the identification of strains and species of schistosome. Mol Biochem Parasitol 57: 83-88.

Dias Neto E, Steindel M, Passos LKF, Souza CP, Rollinson D, Katz N, Romanha AJ, Pena SDJ, Simpson AJG 1993c. The use of RAPDs for the study of the genetic diversity of Schistosoma mansoni and Trypanosoma cruzi, p. 339-345. In SDJ Pena, DNA Fingerprinting: State of the Science, Birkhäuser Verlag Basel, Switzerland.

Gasser RB, Stewart LE, Speare R 1996. Genetic markers in ribosomal DNA from hookworm identification. Acta Tropica 62: 15-21.

Hope M, McManus DP 1994. Genetic variations in geographically isolated populations and subspecies of Oncomelania hupensis determined by a PCR-based RFLP method. Acta Tropica 57: 75-82.

Jarne P, Delay B 1991. Populations genetics of freshwater snails. Tree 6: 383-386.

Jarne P, Delay B, Bellec C, Roizes G, Cuny G 1990. DNA fingerprinting in schistosome vector snails. Biochem Genet 28: 577-583.

Jarne P, Delay B, Bellec C, Roizes G, Cuny G 1992. Analysis of mating systems in the schistosome-vector hermaphrodite snail Bulinus globosus by DNA fingerprinting. Heredity 68: 141-146.

Jelnes JE 1986. Experimental taxonomy of Bulinus (Gastropoda: Planorbidae): the West and North African species reconsidered, based upon an electrophoretic study of several enzymes per individual. Zool J Linn Soc 87: 1-26.

Kane, RA, Rollinson D 1994. Repetive sequences in the ribosomal DNA internal transcribed spacer of Schistosoma haematobium, Schistosoma intercalatum and Schistosoma mattheei. Mol Bioch Parasitol 63: 153156.

Knight M, Brindley PJ, Richards CS, Lewis FA 1991. Schistosoma mansoni: use of a cloned ribosomal RNA gene probe to detect restriction fragment length polymorphisms in the intermediate host Biomphalaria glabrata. Exp Parasitol 73: 285-294.

Langand J, Barral V, Delay B, Jourdane J 1993. Detection of genetic diversity within snail intermediate hosts of the genus Bulinus by using random amplified polymorphic DNA markers (RAPDs). Acta Tropica 55: 205-215.

Larson SE, Anderson PL, Miller NA, Cousin CE, Richards CS, Lewis FA, Knight M 1996. Use of RAPD-PCR to differentiate genetically defined lines an intermediate host of Schistosoma mansoni, Biomphalaria glabrata. J Parasitol 82: 237-244.

Lewis FA, Knight M, Richardes CS 1997. A laboratorybased approach to biological control of snails. Mem Inst Oswaldo Cruz 92: 661-662.

Mascara D, Morgante JS 1991. Enzyme polymorphism and genetic structure of Biomphalaria tenagophila (Gastropoda, Planorbidae) populations: founder effect. Rev Bras Gen 14: 631-644.

Mascara D, Morgante JS 1995. Use of isozyme patterns 
in the identification of Biomphalaria tenagophila (D' Orbigny, 1835) and B. occidentalis (Paraense, 1981) (Gastropoda: Planorbidae). Mem Inst Oswaldo Cruz 90: 359-366.

Michelson EA, Dubois L 1978. Susceptibility of Bahian populations of Biomphalaria glabrata to an allopatric strain of Schistosoma mansoni. Am J Trop Med Hyg 27: 782-786.

Mulvey M, Vrijenhoek RC 1981. Genetic variation among laboratory strains of the planorbid snail Biomphalaria glabrata. Biochem Genet 19: 1169-1182.

Mulvey M, Vrijenhoek RC 1982. Population structure in Biomphalaria glabrata examination of an hypothesis for the patchy distribution of susceptibility to schistosomes. Am J Trop Med Hyg 31: 1195-1200.

Mulvey M, Newman MC, Woodruff DS 1988. Genetic differentiation among West Indian populations of the schistosome-transmitting snail Biomphalaria glabrata. Malacolology 29: 309-317.

Noyes HA, Belli AA, Maingon R 1996. Appraisal of various random amplified polymorphic DNA-polymerase chain reaction primers for Leishmania identification. Am J Trop Med Hyg 55: 98-105.

Paraense WL 1955. Self and cross-fertilization in Australorbis glabratus. Mem Inst Oswaldo Cruz 53: 285-291.

Paraense WL 1959. One-sided reproductive isolation between geographically remote populations of planorbid snail. American Naturalist 93: 93-101.

Paraense WL 1975. Estado atual da sistemática dos planorbídeos brasileiros. Arq Mus Nac Rio de Janeiro 55: 105-128.

Paraense WL 1981. Biomphalaria occidentalis sp.n. from South America (Mollusca: Basommatophora: Pulmonata). Mem Inst Oswaldo Cruz 76: 199-211.

Paraense WL 1984. Biomphalaria tenagophila guaibensis sp. n. from Southern Brazil and Uruguay (Pulmonata: Planorbidae). I. Morphology. Mem Inst Oswaldo Cruz 79: 465-469.

Paraense WL 1988. Biomphalaria kuhniana (Clessin, 1883), planorbid mollusc from South America. Mem Inst Oswaldo Cruz 83: 1-12.

Paraense WL, Corrêa LR 1963. Variation in susceptibility of populations of Australorbis glabratus to a strain of Schistosoma mansoni. Rev Inst Med Trop São Paulo 5: 15-22.

Paraense WL, Pereira O, Pinto DB 1955. Um aspecto da ecologia do Australorbis glabratus que favorece a reinfestação dos criadouros. Rev Serv Esp Saúde Públ 7: 573-581.

Paraense WL, Pointier JP, Delay B, Pernot AF, Incani RN, Balzan C, Chrosciechowski P 1992. Biomphalaria prona (Gastropoda: Planorbidae): A morphological and biochemical study. Mem Inst Oswaldo Cruz 87: 171-179.

Pires ER, Vidigal THDA, Teles HMS, Simpson AJG, Carvalho OS 1997. Specific Identification of Biomphalaria tenagophila and Biomphalaria occidentalis populations by the Low Stringency
Polymerase Chain Reaction. Mem Inst Oswaldo Cruz 92: 101-106.

Remigio EA, Blair D 1997a. Molecular systematics of freshwater snail family lymnaeidae (Pulmonata: Basommatophora) utilising mitochondrial ribosomal DNA sequences. J Moll Stud 63: 173-185.

Remigio EA, Blair D 1997b. Relationships among problematic North American stagnicoline snails (Pulmonata: Lymnaeidae) reinvestigated using nuclear ribosomal DNA internal transcribed spacer sequences. Can J Zool 75: 1540-1545.

Simpson AJG, Dias Neto E, Vidigal THDA, Pena HB, Carvalho OS, Pena SDJ 1995. DNA polymorphism of schistosomes and their snail hosts. Mem Inst Oswaldo Cruz 90: 211-213.

Strahan K, Kane RA, Rollinson D 1991. Development of cloned DNA probes for the identification of snail intermediate hosts within the genus Bulinus. Acta Tropica 48: 117-126.

Stohard JR, Rollinson D 1996. An evaluation of random amplified polymorphic DNA (RAPD) for the identification and phylogeny of freshwater snail of the genus Bulinus (Gastropoda: Planorbidae). J Moll Stud 62: 165-176.

Stohard JR, Rollinson D 1997. Molecular characterization of Bulinus globosus and B. nasutus on Zanzibar, and an investigation of their roles in the epidemiology of Schistosoma haematobium. Trans R Soc Trop Med Hyg 91: 353-357.

Stohard JR, Hughes S, Rollinson D 1996. Variation within the internal transcribed spacer (ITS) of ribosomal DNA genes of intermediate snail hosts within the genus Bulinus (Gastropoda: Planorbidae). Acta Tropica 61: 19-29.

Vidigal THDA, Dias Neto E, Carvalho OS, Simpson AJG 1994. Biomphalaria glabrata: Extensive genetic variation in Brazilian isolates revealed by random amplified polymorphic DNA analysis. Exp Parasitol 79: 187-194.

Vidigal THDA, Neto ED, Simpson AJG, Carvalho OS 1996. A Low Stringency Polymerase Chain Reaction approach to identification of Biomphalaria glabrata and Biomphalaria tenagophila intermediate snail hosts of Schistosoma mansoni in Brazil. Mem Inst Oswaldo Cruz 91: 739-744.

Vidigal THDA, Spatz L, Nunes ND, Simpson AJG, Carvalho OS, Dias Neto E 1998. Biomphalaria spp: Identification of the intermediate snail hosts of Schistosoma mansoni by polymerase chain reaction amplification and restriction enzyme digestion of the ribosomal RNA gene intergenic spacer. Exp Parasitol 89: 180-187.

Welsh J, McClelland M 1990. Fingerprinting genomes using PCR with arbitrary primers. Nucleic Acids Res 18: 7213-7218.

Williams JGK, Kubelick AR, Livak KJ, Rafalski JA, Tingey SV 1990. DNA polymorphisms amplified by arbitrary primers are useful as genetic markers. Nucleic Acids Res 18: 6531-6535. 